\title{
Redeeming the Age in Which We Live: Ignazio Silone's The Story of a Humble Christian
}

\author{
Kimberly Rae Connor ${ }^{\mathbb{D}}$ \\ School of Management, University of San Francisco, 2130 Fulton Street, San Francisco, CA 94117, USA; \\ connork@usfca.edu
}

Received: 15 July 2019; Accepted: 20 August 2019; Published: 22 August 2019

\begin{abstract}
This essay explores Ignazio Silone's seldom considered book, "The Story of a Humble Christian." Part memoir, history, and theatre, this book tells the story of Pope Celestine V, the first, and until Benedict XVI, the only pope to resign. The book lends itself to an interpretation that applies a consideration of Silone's recently revealed and complicated biography with a reflection on the current occupant of the papacy, Pope Francis, as a way to articulate how flawed humans can experience transcendent and transformative possibilities when they lead with humility.
\end{abstract}

Keywords: Ignazio Silone; humility; Celestine V; Pope Francis; leadership; organizational behavior; transcendence; identity

"I would have liked to spend my life writing and rewriting the same story, in the hope of understanding it at least, and of making it understood by others"

-Ignacio Silone

The Story of a Humble Christian

The story Ignacio Silone tried to understand and to have understood was "the fate of a certain type of man, how a certain type of Christian fits into the machinery of the world" (Silone 1970, p. 12). Although needing to rewrite implies failure, in Silone's formulation, the failure, while his, is not his alone. Failing to fit a humble Christian in to the machinery of the world is characteristic of human organizations built by flawed individuals. However, the need to rewrite also implies hope, for the author and for his readers, that the story one day will be understood by others. For this to happen, for hope to be restored and for a story to be heard, Silone recognizes that imminence must be interrupted by transcendence. This happened for Silone when he became a writer and reclaimed his brutalized faith in both God and humanity. In turn, he dedicated his career to writing about those episodes in history when human frailty did not prevent a remarkable event from occurring, when history is also beyond history, like the election of an unlikely Pope, or two, seven centuries apart. Literature proved for Silone to be a valuable medium for explaining how human encounters with a transcendent God could overlap with unique historical and personal narratives. These narratives honored a traditional past but one in need of reform, in which the meeting between transcendence and history was temporary, almost liminal; but they also anticipated and challenged humanity to move towards a liberationist future where the machinery of the world makes a place for a humble Christian.

The work of literature from which I took the epigraph by Silone is the small, seldom considered, but remarkably astute and prescient The Story of a Humble Christian. Published in 1968, Silone's book explores extreme situations in which a good man finds himself torn between the demands of action and the constraints of morality, the requirements of office and the call of conscience, and individual needs and collective responsibilities. The author offers no solution to this enduring challenge but instead 
provides an example of human nature at its best in confronting it and welcoming a transcendent interruption when it arrives. It is the story of the humble Christian, Fra Pietro, known to history as Pope Celestine V. As explored by Jon M. Sweeney (2012) in his comprehensive study, The Pope Who Quit: A True Medieval Tale of Mystery, Death, and Salvation, Peter Morrone-Fra Pietro-was a hermit who founded an ascetic religious order who, by a stroke of fate, was appointed the most powerful man in the Catholic Church. Half a year later, he abdicated the chair of St. Peter. What led him to make that decision drew Silone to his story. It is the mystery of the good man, his appearance and absence, his persistence and frustration, that absorbs Silone for reasons literary and spiritual, immanent and transcendent.

The story Silone wishes to write over and over is also his own. Recent scholarship has revealed the complicated journey Silone took towards being the writer of conscience in search of good men to portray in fiction; he was also searching to find one in himself. In telling the story of Fra Pietro, Silone was also telling his own story. The biographical evidence that came to light only after his death that complicates our understanding of Silone's conduct does not change the moral force of his work or the substance of his character. Rather his character is made more real, fully reflective of humanity's struggle to be good: "to make the choice that his conscience dictates" (Silone 1970, p. 27). As Silone did in fascist Italy, we continue to face conflicts in assessing the moral authority of our cultural, civic, and religious leaders. We endure what Fra Pietro did in the 13th century_-educated men ... " [who] try to get out of it with a few remarks that were neither fish nor fowl" (Silone 1970, p. 40).

The author points us to where we are institutionally and how we should proceed personally with the following statement: "After having lived through the loss of innocence, to go back and pretend to accept a system of dogmata whose validity is no longer recognized as absolute would be to suppress reason, to violate one's conscience, to lie to oneself and others, and to insult God" (Silone 1970, p. 32). The example he provides to support this factual evidence is the story of the brief tenure of Pope Celestine V (1215-1296), one of the most unlikely, unsuited, and short-serving pontiffs in the history of the Catholic church.

While Fra Pietro may have had a Franciscan charism, historically he was a Benedictine and not a Franciscan. Still, as a hermit, he was uncomfortable in the halls of power, Celestine V was seen differently by history for his resignation after three months. In 1321 Dante infamously characterized Celestine $\mathrm{V}$ as the character indicted in the third Canto of the Inferno, the man who "out of cowardice made the great refusal" (Silone 1970, p. 204). This image shaped historical perceptions, Silone points out in his helpful annotated commentary, and was influenced by Dante's hatred of Boniface VIII, the pope who succeeded Celestine V after his abdication. But Petrarch, in the 1346 treatise De vita solitaria, provides an impassioned apologetic on behalf of Pier Celestine, offering the miracle of heavenly light that surrounded the pope after he renounced his office. He laments he had not lived alongside Celestine: "This gesture (the abdication) of the solitary and Holy Father may be attributed by those who will to cowardice of spirit, since the diversity of temperaments allows us to express on the same argument opinions which are not only different but conflicting. For myself I believe the gesture was above all useful to himself and to the world ... . I consider his act as the act of a most lofty and free spirit which knew no impositions, of a truly divine spirit; and I think a man could not have so acted if he had not rightly evaluated human affairs, and had not set beneath his foot the proud head of fortune ..." (Silone 1970, p. 205).

It was Silone's hope in writing The Story of a Humble Christian that "Celestine can help us ... in avoiding the temptations of power" (Silone 1970, p. 18) that Silone witnessed during World War II. As the author writes describing the thesis of his own work and his choice of subject: "The drama of Celestine's predicament for a long period lay in the illusion that the two different ways of following Christ - the history of Utopia and the history of the church and her compromises with the world could approach each other and unite. However, when Celestine was forced to choose between them, he didn't hesitate" (Silone 1970, p. 25). When Silone invokes "utopia," he is not signaling the transcendent. Rather he is observing the ways we settle for a cheap version of transcendence characterized by a 
utopian church made up of and run by flawed humans in need of the transcendence recognized in the historical interruptions that point us towards hope.

When he begins the book, Silone invites the reader to consider his biography-at the time of writing not fully revealed-describing for the reader the pilgrimage that took him back to his home region in order to research his subject, Fra Pietro, who came from the same part of Italy. "What Remains" is a four-part personal reflection that combines myth, history, and memoir. It comprises the author's preparation - archival and actual—to set the context for what follows: a short, dialogue-driven six-act play, "The Story of a Humble Christian," that dramatizes the moral testing, heroism, and eventual failure of Fra Pietro Angelerio who in 1294 was called by the cardinals to leave his mountain retreat, where he had shepherded a community of ascetic monks, to become Pope Celestine V. He held the papacy for 3 months while he tried to remain faithful to his former way of life. He was unsuccessful and retreated until he was hunted and imprisoned by his successor, Boniface VIII, and died shortly thereafter.

Told from the perspective of the village folk, friars, and servants as a challenge to the official history of the church hierarchy, Silone positions the reader for discernment on where to find truth by prioritizing these marginalized points of view. "When the occasion demands ... dreamers and ordinary folk are capable of exceptional acts of generosity and courage" (Silone 1970, p. 17) and "in certain times and places," their union "assumes an eschatological force" (Silone 1970, p. 22). Their moral authority as narrators of Fra Pietro's story is summed up by Concetta, the poor weaver who starts the action in the play. As she unspools the tale "about men quarrelling among themselves, men of the church, arguing about how to interpret the "Gospel and the Rule laid down by Saint Francis just a few dozen years ago ... ", she doesn't hesitate to observe that "religion concerns women at least as much as it does men'"' (Silone 1970, p. 38). Concetta has been protecting Fra Pietro and his followers who have been hiding in mountain caves from the ecclesiastical authorities who wish to charge them with apostasy: "The main reason I help these friars is, after all, quite simple; it's because they are persecuted for questions of conscience" (Silone 1970, p. 45). Concetta herself becomes a target of the authorities when she challenges their accusations of being disloyal to the Church: "Since when has a special permission been necessary for works of mercy?" (Silone 1970, p. 47), Concetta asks, as the conscience of the community.

Silone takes his time in drawing an appreciative picture of this community's ethos-its humor, its kindness, its courage—as a model for society and the Church. "In our Father's house there are no masters, mistresses or servants, but only children, all free and equal" (Silone 1970, p. 52). He also establishes the moral clarity of the friars who follow and protect Fra Pietro, in whom it "seemed Christ returned to earth" (Silone 1970, p. 59), a gentle reference to the attention required of us to recognize transcendence when it appears. Rather than hide, they challenge the ambitious local priest on his corrupted priorities, the "abyss dug by the degeneration of our church and by the betrayal of the spirit of Saint Francis on the part of many who take his name. This betrayal was made possible with the help of the pope, the bishops, and priests" (Silone 1970, p. 53).

Silone establishes early the ongoing conflict between an institution and an individual. As one friar explains, the Church has a problem of scale and priorities. It is operating like a business rather than ministering like a church and as such perpetuating structural inequalities:

A large community is a dangerous, almost diabolical machine, even for those who are part of it. Experience shows us that a large community spontaneously kindles ambition for power, desire-never really sated-for success and triumphs. In the noble aim of advancing the community, constant compromises and adjustments are accepted. Does this happen because of the leaders' ambition or because of the flocks' demands? I don't know, it may be that in most cases the two egoisms are united, and I'm willing to assume that the leader's intentions are good. In other words, it seems natural to me that, in the interest of the community, and to the greater glory of God, an abbot or a prior or a guardian might not want to arouse the hostility of the authorities, or of the rich, since he needs their help to establish new convents, build new churches, obtain new bequests, dispensations, privileges, winning them 
away from rival communities. As a community gradually becomes larger, it inevitably resembles the society that surrounds it. And then? What becomes of the salvation of the flock? (Silone 1970, p. 67).

This is the machinery that has no place for a humble Christian like Fra Pietro. Through these voices, Silone firmly establishes the terms of moral governance and illustrates that any leadership under current structures demands compromises a saint cannot accept. As well, Fra Pietro, now sought by authorities and soon to be called to the papacy, is such a man. "What can I tell you? Perhaps this is enough: all in all, he is truly a good Christian," one of his friars pronounces (Silone 1970, p. 65).

Fra Pietro arrives at end of the first act after an extended period of private contemplation, and his habits of modest dress establish the symbolic manners of his humility (a practice he continues even after elected pope). Yet immediately he also demonstrates that humility is not passivity when he challenges the authorities who are threatening his followers and protectors: "Now it's true that we first become Christians through the grace of baptism, but we remain true Christians only if we love one another. Jesus said this and, mind you, it wasn't simply a figure of speech" (Silone 1970, p. 68). Here through Fra Pietro, and elsewhere in the dialogue of the play, Silone invokes a law higher than ecclesiastical: the law of Christ. By his actions and his words Fra Pietro affirms core Christian values. But he also shows a clever way to lead through a moral quagmire when he uses his wits, a technique common to those denied traditional protection from power, to avoid prosecution for himself and his followers. Engaging the technique deployed by the folk and by Christ, teaching by parable, Fra Pietro relates a story about cooked beans to protect Concetta from arrest for theft, turning the authority's arguments back on them. He dismantles their elaborate accounting methods and "precise calculation" by observing that no matter the math, the sum is the same: what remains is "a bit of manure" (Silone 1970, p. 79).

Here and elsewhere Fra Pietro's character is established by traits he shares not just with Christ or St. Francis but also with marginalized humans struggling to survive by wits and faith. In an extended reminiscence, one of the friars tells several parables about Fra Pietro that further identify him through his human encounters with the transcendent spirit of Saint Francis and the immanent spirit of the folk. The friar described Fra Pietro's encounters with animals, whom he always named as individuals. From the fox he befriended and freed but did not try to tame, to a viper and a cricket, nothing escaped his attention, reverence, and devotion. The friar further extended the sustaining myth that invited transcendence in the ordinary, noting that Fra Pietro meditated so deeply he could hear grass growing, sang psalms at bedtime until he fell asleep, and was so unschooled in society that he drank water from a finger bowl. Combined these characterizations and the words of the character of Fra Pietro prepare us for recognizing how unsuited he is for the papacy and how the drama will likely unfold, despite its transcendent dimensions.

Act II begins the action two months later after the historically chronicled moment of transcendence: the "miraculous choice" of Fra Pietro as Pope (Silone 1970, p. 81). The setting is described in language reminiscent of Petrarch, as surrounded by a miracle of clean air and changed weather that inspires people to renew their faith. "The dove has prevailed over the eagle. You, too, should open your heart to hope," one friar urges another (Silone 1970, p. 83). Soon to be Celestine V, Fra Pietro arrives at his order's hermitage to face a skeptical Vatican advance team and demonstrates how ill-suited he is to assume the symbols of power, despite his agility engaging the parish priest. As he explains, reaffirming his identification with St. Francis and the people:

I didn't mean to establish a rule, or to teach others a lesson. But, for myself, I feel that if I began to prefer a horse to the donkey, fine silk clothing to rough cloth, a richly set table to plain humble board, I would start thinking and feeling like those who ride horses, live in grand drawing-rooms and eat banquets. Personally, I don't think religious authority has any need of luxury to inspire respect. In any event, even in my new station, I don't intend to abandon the way of living of the poor, to whom I belong. (Silone 1970, p. 87) 
Discerning this call to the papacy through an examination of his conscience, Fra Pietro turns to “divergent inspirations. If I accept ... won't I be sinning in my presumption? I'm a humble, ordinary Christian; how can I dare become the vicar of our Lord among men? Then this doubt was followed by another, its exact opposite. And I rather than commit the sin of presumption, I were committing the sin of cowardice, lacking faith in the Holy Spirit and his assistance?" (Silone 1970, p. 88). Rather than ridiculing this astute manner of decision-making, Silone offers it as evidence of sincerity when the people, upon hearing Fra Pietro has accepted the call, proclaim "Finally we'll have a pope who believes in God" (Silone 1970, p. 89).

Subsequent acts of the play waste no time moving quickly through scenes that illustrate the inevitable downward trajectory of Celestine V's papacy. Persisting in his ascetic ways, the pope experiences the "repugnance of the Roman Curia" (Silone 1970, p. 90) and personalizes his role as leader: "But the most painful wounds are those I receive from my own family. I am ashamed before God, because responsibility for the misdeeds of the family falls on the father first of all" (Silone 1970, p. 93). Celestine tries to approach an audience of Cardinals applying his familiar method for managing his followers, by using the techniques of the folk: Telling parables, talking "as a father to his children" (Silone 1970, p. 96). He does so gently, speaking indirectly, as he is schooled to do by his life on the margins, to the topic of what should constitute a homily; the cardinals, of course, are unaware that he is practicing on them the very technique he is encouraging them to adopt—speak simply and directly to the people. In an explicit association of transcendent blessing with the discourse of the oppressed, Silone characterizes Celestine V, the highest ecclesiastical authority, as deploying "the ingenuousness of the saints" (Silone 1970, p. 104), when he encourages the Cardinals: "Try to be simple ... To succeed we have to be simple within ourselves, and true simplicity is a difficult achievement. A Christian's whole existence, you might say, has precisely this aim: to become simple," because "Christianity, in fact, is not a way of speaking, but a way of living" that extends to how they see their roles as leaders in the church: "Try to be good Christians, do good and do it with all your hearts. Don't do it out of cleverness, or for profit, or to be popular or to advance your career. Do good gratuitously and tell nobody about it" (Silone 1970, p. 97).

But Celestine V cannot sustain this hopeful tone. Facing the corrupt way of doing business in the Vatican, the overwhelming size of the tasks he must accomplish, and the decisions he must make without contemplative reflection, leads him to despair. "Why didn't you leave me in the mountains among my poor people?" (Silone 1970, p. 102). Celestine V tries to reform the curia and distribute responsibility among the cardinals but only finds resistance.

In a remarkable exchange that students of leadership would be advised to consult as an example of the ways that people serving institutions lose their moral compass, a cardinal lays out Vatican thinking on organizational behavior: "No great political or military or religious organization can be governed like a family or like a small community. There's an enormous difference. Every great organization, if it is to function regularly, needs a certain number of pretenses, without which it would lapse into chaos ... It's not a matter of outright falsehood, but of conventions". The Cardinal's rationalization of the way the Church has adopted a corporate mentality, returns Celestine V to reason in the form of direct evidence from the life of Christ to support his organizational model:

You'll probably pity me, when I tell you that, even in questions like this, I still go no farther than the Pater Noster and the Gospel. In the parables of the gospel, you know as well as I, relations between men are always personal and direct. There is always the father with his sons or his servants; the owner of the vineyard with the workers; the shepherd with his sheep and his lambs; and so on. There are never indirect, anonymous relations, or pretenses, or, as you would say conventions. So, you must forgive me if I cannot conceive Christian relations that are not personal relations. I mean to say: relations between souls, not things.

There are forces that drive men to become more and more alien to one another. But isn't it our Christian duty, in every new situation, to preserve the possibility for men to stay together? To understand one another, to love one another? (Silone 1970, pp. 110-11). 
In this extended exchange, Celestine $\mathrm{V}$ again and again turns to a relational archetype for leading his flock and resists the transactional ways he discovered the Vatican asserting power, a method that sustains structural inequality. The Church hierarchy represented an organization that had lost sight of its mission. Christianity, Celestine V reminded them, is made up of "souls, not things. I can't treat Christians like objects, like stones, like chairs or tools, or even like subjects ... For Christians the supreme value lies in our consciences". (Silone 1970, p. 112)

As his ambivalence grows, Celestine V "fear[s] I will never be pope entirely," because he refuses to perfunctorily perform the tasks of prior popes that he finds contrary to mission, like taxing whore houses to finance church improvements or blessing a nobleman's army heading out to battle (Silone 1970, p. 117). As he observes in defending his position: "Faith cannot be separated from hope and charity. How can we allow the infamous titles of Christian armies, Christian wars, Christian persecutions, and other ignominy of that sort?" ... You can't kill for a good end. To good ends you can do only good, love, help one another, forgive" (Silone 1970, p. 181). So, during Advent, the season of retreat and waiting, Celestine $\mathrm{V}$ abdicates his role and returns to the caves from where he came. What follows in the final act is dialogue between the followers of Fra Pietro who are still loyal to him and who also protect him, aware that Celestine V's successor, Boniface, wants to punish and possibly kill Fra Pietro because he was not made of the "wood they make their puppets with" (Silone 1970, p. 125).

What Fra Pietro learned during his short tenure as Celestine V-the story Silone wanted to tell again and again - was about the nature of power, how "the exercise of command enslaves, starting with those who exercise it" (Silone 1970, p. 125). Neither does popularity sway Fra Pietro: "We must love the people, but no uproar of the crowd must ever prevail over the voice of conscience" (Silone 1970, p. 137). Fra Pietro accepts Boniface's persecution as penance for his actions but also recognizes the new pope's conduct for what it is: "stupid and unjust, like all actions inspired by fear. When an ambitious and weak man is seized with panic, he inevitably sees dangers everywhere and falls back on the most absurd falsehoods" (Silone 1970, p. 148). Anticipating a long "examination of conscience," as is his habit of being, Fra Pietro sums up the lesson that was reinforced when he tried to lead an organization that had strayed from its mission: "I thought I could make use of the king 'to good ends.' That cursed phrase. There is only good, pure and simple. There are no 'good ends'"' (Silone 1970, p. 149).

This moral pronouncement could also be applied to the lesson learned by Ignazio Silone whose experience taught him about the institutional limits of human organizations and the endless possibilities of the human soul when it welcomes a transcendent encounter. After a crisis-inducing episode in his past, Silone became a writer in order to affirm the truth of the words he has Fra Pietro speak: "If we can't convince each other, let's try to at least understand each other. When we talk of the reality that must be taken into consideration, you refer to institutions and to power, I refer to souls. God created souls, not institutions. Souls are immortal, not institutions, not kingdoms, not armies, not churches, not nations ... The task of Christianity is to redeem through truth." (Silone 1970, p. 181).

Although the author demurs when he writes "I don't consider myself a missionary," he was a writer who had seen war and betrayal and the loss of faith in traditional institutions, who understood that "any reality looks different, seen from the outside" (Silone 1970, p. 31). The reality he explores in The Story of a Humble Christian is the Church as a "noble, a venerable superstructure," while asking, "but what happens to poor Christ in such a superstructure?" (Silone 1970, p. 32). He asks this question after having lived through the "loss of innocence" he describes in an earlier quotation; and he seeks "what remains" after the loss of innocence: "a Christianity without myths, reduced to its moral essence. ... and the Pater Noster" (Silone 1970, p. 33).

In this work Silone combines the historical record with a myth of a saint and the recollections of a broken man (who only reveals part of what broke him) struggling to convert back to his faith. Writing, and perhaps especially writing Fra Pietro's story, became an act of moral reinvention, providing a new model for ethical engagement in how one responds to power. As the historical record presented opposing characterizations of cowardice and courage in Celestine V, so too do such oppositions 
characterize the life of the author, who at the time of the publication of the book's English translation in 1970 was heralded by the critic Irving Howe (1971) as the perfect writer for his post-war, post-Vatican II times, one "whose every word yields a radiance of good faith, a pleasure of spirit that is indifferent to power and hostile to ideology" (Howe 1971, p. 39). Writing for The New Yorker, Alexander Stille (2000) observed that throughout his literary career, Silone had been regarded as a "secular saint, a man of rare intellectual and moral courage, who had opposed Fascism from the start and endured years of exile and persecution for his beliefs ... Personal integrity was the central feature of his work" (Stille 2000, p. 44). As characterized by Howe in the 1970s, and for the rest of his life, Silone was seen as "a churchless Christian and a partyless Socialist who keeps returning to a central problem of modern life: the problem of power, its tendency to corrupt those who hold it, to leave impotent those who refuse it, and to torment those who wish to shorten the distance between the ends for which they suppose themselves to live and the means by which they do live" (Howe 1971, p. 40).

Ernesto G. Caserta supports this noble characterization of Silone in an essay in Italian Quarterly and provides biographical details of near-mythic proportions to endorse this portrait (Caserta 1972). Caserta demonstrates that as a member of the Italian Communist Party from 1921-1931, Silone was an active supporter for personal, social, ethical, and spiritual reasons. However, after his brother, also a Party member, was killed in the Resistance, Silone fled to Switzerland and while there broke with the Party and became physically ill. To recover, he took refuge in the people and landscape of Fontamara, a village in his home Abruzzo region. Believing he is dying, Secondino Tranquilli (the baptismal name given the author) adopts the pseudonym Ignazio Silone. Thereafter, he becomes the person he names after a saint who also made a dramatic conversion and became a writer of conscience. Eventually he writes about the pope who also came from his beloved Abruzzo region as an example of the kind of man he seeks to write about and understand throughout his literary career.

Yet as Stille points out in his essay, "The Spy Who Failed: Did the Great Anti-Fascist Novelist Ignazio Silone Betray His Cause?" research in recent years has turned up documents in Italian police archives that strongly suggest that Silone, as Tranquilli, in the decade before he became a writer, acted as an informant for the Fascist police who were investigating subversive groups during the Mussolini years. Faced with these revelations, some supporters offered that perhaps Tranqulli (known in police records as the informant "Silvestri,") was a double agent; but none can account for all of what the historical record reveals. These new details about his biography and his name change, as well as reasons practical, personal, and perhaps necessary, add additional intensity to his choice to abandon politics and become a novelist and to write about uncompromising moral characters.

Correspondence between Silone and a police official in Rome suggest a growing guilt and resulting refusal that led to Silone's breakdown and retreat to Switzerland: "My health is terrible and the cause is moral ... A sense of morality, which has always been strong in me, now overwhelms me completely; it does not permit me to sleep, eat, or have a minute's rest. I am at a crossroads in my life and there is only one way out: I must abandon militant politics completely. The only other solution is death. Continuing to live in a state of ambiguity has become impossible, impossible. I was born to be an honest landowner in my hometown. Life has thrown me along a course that I know I want to leave behind." (Stille 2000, p. 48).

His lament sounds not unlike Fra Pietro's struggle to perform the papacy in a transactional way, as a kind of traitor to Christianity, just as Silone felt complicit working for the police. However, unlike Fra Pietro, who unsuccessfully tried to return to his former life, eventually dying in prison as a victim of a corrupt organization, Silone recognized that he could not return to his former life. After the war, it didn't exist anymore. The split with communism, the experience with fascism, and the breakdown of his health, all led him to regain the core of faith-"'good is often born of evil, and that I would not have become a man without having passed through the infamies and errors committed" (Stille 2000, p. 48).

So, in his moment of greatest absence, he welcomed a transcendent transformation. He re-invented himself, put on the mask of writer, and became the moral hero he had always tried to be but for a brief period failed to be. Although he didn't reveal his complicity during his lifetime, and we may 
never know the motive or cause of his coercion, by engaging writing as an act of moral reinvention, Silone, like his protagonist Fra Pietro, provides a model for ethical leadership and its relationship to power. Silone writes: "I will start a new life, on a new basis, in order to repair the evil that I have done, to redeem myself, and to do good for the workers and the peasants (to whom I am bound with every fiber of my heart) and for my country ... If you are a believer, pray to God that he give me the strength to overcome my remorse, to begin a new life, and to live it for the good of the workers and of Italy" (Stille 2000, p. 48). Silone, like Fra Pietro, learned through painful experience that the ends do not justify the means.

In writing The Story of a Humble Christian, Silone re-enacts his own drama of betrayal and redemption, of the individual caught in the machinery, all while still validating the role that Howe had articulated in 1968 while describing Silone to his New York Times readers as a writer who bears witness to moments of transcendence as it interrupts history:

What can a writer do-I mean the kind of writer who yields himself to the political struggles of his time yet wishes to remain faithful to his calling and his craft? He can bear witness and tell the truth. He can assault the cant of brutal men in power and of the hard-spirited ideologues lusting for power. He can tell us stories and fables that recall the imagination to humanness. And if he is brave, stubborn, and unafraid of loneliness, he can even help redeem the age in which he lives". (Howe 1971, p. 39)

The more complicated Silone we now know upholds Howe's redemptive vision of him and illustrates what he shares with the protagonist in The Story of a Humble Christian. Like Fra Pietro, Silone was betrayed by people, institutions, and doctrines he trusted. He also started his career as an outsider. $\mathrm{He}$, too, tried to work with power but found the cost on his conscience too high. As well, like Fra Pietro, Silone experienced a conversion back to his true self and returned to a principled life but with a new name and writing as a mission. In choosing Ignazio for his new name, however, the writer could not have known that long after his death in 1948, this choice would evoke a comparison with another humble Christian whom Silone would probably want to write about, someone whose relationship to power and modest way of moving through the world recalls Fra Pietro and his predecessor in humility and charism, St. Francis: the Ignatian-formed Jorge Mario Bergoglio. As Fra Pietro escaped to Marrone and Ignatius escaped to Manresa, and later Silone escaped to Abruzzo, all in search of what it means to live like a humble Christian and to receive transcendent truth, now all are coming together in the new protagonist of the story we are trying to understand in our times, the most recent transcendent interruption of history: Pope Francis.

Considering The Story of a Humble Christian in its extended context-including the archival record, the author's text, and Silone's biography-we can see, as we do in scripture, several narrative genres at play: history, myth, and autobiography. All these narrative perspectives combine to bring us to our current times where the same genres apply but to a new narrative voice that has emerged in the person of Pope Francis. His name recalls the humility of the Celestine V's posture and his actions continuously generate new myths, as Silone did, of how flawed humans can be humble Christians in the world. However, unlike Silone and Fra Pietro who remained outsiders to institutional influence and rejected the responsibilities of power, Pope Francis chose to enter the fray and write a new kind of history as a pope willing to make bold changes to an organization whose historical and current reputation is morally ambiguous to many. Rather than retreat to the mountains as Fra Pietro did, or to hide in writing as Silone did, Jorge Bergoglio became a pope rooted in Franciscan humility but driven by Ignatian fire.

Fulfilling the hope of Silone that "there will always be some Christians who will take Christ seriously, some absurd Christian," the character of Pope Francis resolves the paradoxes of Fra Pietro, whose conscience couldn't let him fully become Celestine V and of Secondino Tranquilli, whose conscience converted him to Ignacio Silone (Silone 1970, pp. 150-51). "Power doesn't attract me," Pope Celestine proclaimed. "I find it essentially wicked. The Christian commandment which sums up all the other is love.... I have become more aware than I was in the past that the root of all evils, 
for the Church, lies in the temptation of power" (Silone 1970, p. 180). The Jesuit trained Pope Francis has a similar perspective. Just as Fra Pietro initially refused the call to the papacy, so Father Bergolio remarked in an address to students, "No, I did not want to be pope. Is that okay?" (Lowney 2013, p. 13).

Jesuits are instructed by their Constitutions to "promise to God our Lord never to seek high office" and to avoid ambition (Padberg 1996). So like Fra Pietro, Father Bergoglio took a paradoxical path to power and applied examinations of conscience and discernment to understand how to use that power. Father Bergoglio, like Fra Pietro, didn't lobby for the role of pope; when Benedict resigned, he went back to Argentina out of the limelight, like Fra Pietro returning to his hermitage, and spent time with the poor. Like Fra Pietro, the First Franciscan pope, Father Bergoglio was the first pope to pick Francis for his name but also the first Jesuit; the first Latin American and the first in sixteen centuries from outside of Europe. His own description of his election is strikingly similar to Fra Pietro's: “The conclave had to give a bishop to Rome.... And it seems my brother cardinals went almost to the end of the world to find one" (Anderson 2018, p. 42).

As pope, Francis eschews the regal garb of the papacy for simple robes, takes buses rather than limos, and lives in a small apartment rather than a grand palace. Just as Celestine V spoke to others "like a father scolding his children" (Silone 1970, p. 113), so too has Pope Francis adopted a relaxed and relational management style, stating "In life, God accompanies persons, and we must accompany them, starting from their situation. It is necessary to accompany them with mercy" (Spadaro 2013, p. 25). As well, as Fra Pietro discerned his papacy through an extended prayer session, Pope Francis knelt for fifteen minutes of solitary prayer on his first morning as pope.

Pope Francis, by virtue of his "ministry of nearness" (Elie 2018) and his Jesuit training to be a "contemplative in action," embodies a description one friar gave to Fra Pietro: "He is a Christian who has had the grace of two vocations and both exceptionally strong, almost irresistible, I'd say: the vocation of the hermit, and the vocation of the shepherd of souls" (Silone 1970, p. 66). Celestine $\mathrm{V}$ was a contemplative but in conflict with action, able only to support a small following, unlike Pope Francis, who is a contemplative in action who leads a global organization as a Jesuit: through accompaniment. As he explains, "In the shoes of the other, we learn to have a great capacity for understanding, for getting to know difficult situations" (Schneider 2017).

Pope Francis has encouraged his priests to become more involved in the lives of their parishioners and communities, to be more like Christ the shepherd, to be shepherds who "smell like sheep," just as Fra Pietro's ministry was validated by scriptural tradition, as one friar observed, when challenged for "meeting in catacombs, or in stables, the way you do." "Sometimes, yes, we do meet in stables. You know why? Certainly not because we love dirt, but because you prevent us from preaching in church. And since Christ was born in a stable, no priest would be allowed to speak of them with scorn, as you do" (Silone 1970, p. 56).

In his short service as pope, Francis has challenged the complacency of the church in ways similar to the reforms Celestine V envisioned. In addressing the abuse by priests, Pope Francis, like Celestine, identifies the root of the problems as "a church that is elitist and clericalist" unable "to be near the people of God" (Wooden 2018). The result is an "abuse of power and conscience (Wooden 2018). He continues, recalling the history related by Silone, "Forever in the church there have been authoritarian bishops and religious superiors. And authoritarianism is clericalism" (Wooden 2018). As well, in advising his curia, Pope Francis turns to scriptural examples, as Fra Pietro did in speaking to his cardinals, reminding them of fifteen sicknesses that have invaded their body, including the sickness of "Marthaism" or excessive industry and functionalism, egotism, hardness, vanity, competition, hypocrisy, gossip, and indifference. These and other traits that characterize a transactional leader, not a relational leader, Pope Francis recognizes as having come to be associated with current Vatican practices that he aims to improve (Martin 2014).

In more pastoral terms, Pope Francis encourages lukewarm Christians and lazy Christians to engage more energetically and not take refuge in a cozy life but to get beyond their comfort zones. 
He constantly iterates that the Church should be poor and for the poor and challenges bishops to embrace poverty, simplicity, and austerity. He cautions that careerism is leprosy and indicts a culture in which money for the mighty of this earth is more important than people. As a relational leader, Pope Francis bathes the feet of juvenile delinquents and wades into a crowd of refugees, goes to confession before hearing confessions of others, washes the feet of Muslim men and homeless women, airlifts Syrians on a papal plane, and provides a homeless shelter in the Vatican (Elie 2018).

Sensitive to acts of power, by Chris Lowney's reckoning, Pope Francis embodies a form of leadership shaped by his Jesuit training which presents spiritual engagement in the form of paradoxes. One should know one's self deeply but live to serve others; immerse one's self in the world but withdraw from the world daily; live in the present and revere tradition but create the future. The vision Pope Francis projects for the future is linked to the past in the organic way Jesuits live in paradox: "Fidelity is always a change, a blossoming, a growth (Lowney 2013, p. 89). The hope for this change, this blossoming is what Silone also hoped to see in the church. Its origins are transcendent, rooted in the story of humble Christians like Fra Pietro, like Silone, and like Pope Francis, who identifies not with the power accorded by his role, but by his kinship with the human condition. Pope Francis, citing a Caravaggio of Matthew and the tax collectors, observes that he is Matthew. "I feel like him ... here, this is me, a sinner on whom the Lord has turned his gaze." (Howell 2014, p. 3). When asked "Who is Jorge Mario Bergoglio?" in an interview for America magazine, he responds: "' I am a sinner" (Gehring 2015, p. 11).

Pope Francis recognizes the Church he leads as "first and foremost a people advancing on its pilgrim way towards God." (Pope Francis 2013, para. 111). In another setting speaking to his bishops, Pope Francis applies different metaphors for the Church that clearly illustrate the attention that drives him to reverence and devotion. "The vineyard of the Lord, the fertile Mother and the caring Teacher, who is not afraid to roll up her sleeves to pour oil and wine on people's wound [sic]; who doesn't see humanity as a house of glass to judge or categorize people" but is "composed of sinners, needful of God's mercy" (Pope Francis 2014).

The relational leadership that Pope Francis practices suggests a specific role for the Church that, "needs to warm the hearts of the faithful ... it needs nearness, proximity" (Elie 2018). His theology of nearness leads him to yet another metaphor. The Church he leads "should be like a field hospital after battle ... it is useless to ask a seriously injured person if he has high cholesterol, or about the levels of his blood sugars. You have to heal his wounds. Then we can talk about everything else." (Brigham 2015, p. 25).

His intimate theology also draws in others who don't typically pay attention to the words and actions of a pope. As Silone the writer extoled Celestine V the pope, so in our era the film director Wim Wenders has chosen Pope Francis as a subject for his documentary work because, "Pope Francis calls St. Francis of Assisi 'the apostle of the ear.' When you lend someone your ear, you are drawing close to that person, drawing near" (Elie 2018). It is this proximity that reminds Pope Francis of his vocation, that the more power one has, "the more you are called on to be humble" (Anderson 2018, p. 44).

The examples of Fra Pietro, Silone, and now Francis, liberating leaders rooted in humility and identification with the least of these, are models not just for clergy or Christians. Their lives are linked to each other and links to ourselves. Their lives are linked to the literary truth and factual evidence before us of how humility can shape our human nature towards its virtuous possibilities. However, in the paradoxical way that Jesuits proceed, Pope Francis will most likely follow the advice that Fra Ludovico offers in the form of a parable to Vatican clerks converted by Fra Pietro's example. Like St. Ignatius he admonishes the followers to "go and set the world on fire," a fire that will illuminate and warm, one that will endure:

There was a fire, not of straw, but a lasting fire which was lighted less than a hundred years ago by St. Francis of Assisi, and despite the angry efforts of many fireman, it is still burning here and there. Why? Wherever Saint Francis appeared, he didn't invite the people to rejoice and forget their cares, but to be converted, to change their life, to replace the frivolous 
pleasures of the world with the joys of the spirit, and he set them an example... Perhaps what Saint Francis needed to spread his fire through all Christendom, was the help of a pope like Celestine V." (Silone 1970, p. 124)

What the overlapping narratives of Fra Pietro, Ignazio Silone, and Pope Francis have in common is the task Silone assigned to all who aspire to be humble Christians who spread transcendent fire:

We have the duty of the housewife who, at night, covers the embers on the hearth with ashes, so she can light the fire more easily the next morning. And then we have the constant task of maintaining links among ourselves and encouraging our scattered friends. When a net is ripped apart, it has to be sewn together all over again". (Silone 1970, p. 151)

They tell the stories we keep writing over and over in the hopes of understanding them and having them understood by others; they glow as embers of transcendent love; they link us among ourselves; they show us how to sew the net back together. Humble Christians trying to fit in to the machinery of the world, they redeem the age in which we live.

Funding: This research received no external funding.

Conflicts of Interest: The author declares no conflict of interest.

\section{References}

Anderson, John. 2018. A Radical Portrait of the Pope, from a Director and a Fan. America, May 28, 42-43.

Brigham, Erin. 2015. The Church as a Field Hospital: The Ecclesiology of Pope Francis. In Pope Francis and the Future of Catholicism in the United States: The Challenge of Becoming a Church for the Poor. Edited by Erin Brigham, David E. DeCosse and Michael Duffy. The Lane Center Series; San Francisco: University of San Francisco, Volume 3, pp. 25-36.

Caserta, Ernesto G. 1972. The Meaning of Christianity in the Novels of Silone. Italian Quarterly 16: 19-40.

Elie, Paul. 2018. The Spiritual Nearness of Win Wenders's 'Pope Francis: A Man of his Word. The New Yorker. May 21. Available online: https://www.newyorker.com/culture/culture-desk/the-spiritual-nearness-of-wimwenderss-pope-francis-a-man-of-his-word (accessed on 21 August 2019).

Gehring, John. 2015. The Francis Effect: A Better Catholic Values Debate in American Public Life? In Pope Francis and the Future of Catholicism in the United States: The Challenge of Becoming a Church for the Poor. The Lane Center Series. Edited by Erin Brigham, David E. DeCosse and Michael Duffy. San Francisco: University of San Francisco, vol. 3, pp. 11-17.

Howe, Irving. 1971. Finally a Pope Who Believed in God. The Story of a Humble Christian. The New York Times Book Review, December 5, 39-42.

Howell, S. J. Patrick. 2014. The People's Pope: A Gift and a Challenge for the Academic World. Conversations 46: $1-5$.

Lowney, Chris. 2013. Pope Francis: Why He Leads the Way He Leads. Chicago: Loyola Press.

Martin, James. 2014. Pope to Curia: 15 Spiritual Ailments to Avoid. America. December 22. Available online: https://www.americamagazine.org/content/all-things/pope-curia-15-spiritual-ailments-avoid (accessed on 21 August 2019).

Padberg, John W. S. J. 1996. The Constitutions of the Society of Jesus and their Complementary Norms: A Complete English Translation of the Official Latin Text. St. Louis: The Institute of Jesuit Sources, Available online: https://jesuitas.lat/uploads/the-constitutions-of-the-society-of-jesus-and-their-complementarynorms/Constitutions\%20and\%20Norms\%20SJ\%20ingls.pdf (accessed on 21 August 2019).

Pope Francis. 2013. Apostolic Exhortation. Evangelii Gaudium. Available online: http: //w2.vatican.va/content/francesco/en/apost_exhortations/documents/papa-francesco_esortazione-ap_ 20131124_evangelii-gaudium.html (accessed on 21 August 2019).

Pope Francis. 2014. Address of His Holiness Pope Francis for the Conclusion of the Third Extraordinary General Assembly of the Synod of Bishops. Synod Hall. October 18. Available online: https://w2.vatican.va/content/francesco/en/speeches/2014/october/documents/papafrancesco_20141018_conclusione-sinodo-dei-vescovi.html (accessed on 21 August 2019). 
Schneider, Nathan. 2017. Bill Gates, Mark Zuckerberg and the Case Against Philanthropy as We Know It. America. June 12. Available online: https://www.americamagazine.org/politics-society/2017/06/12/bill-gates-markzuckerberg-and-case-against-philanthropy-we-know-it (accessed on 21 August 2019).

Silone, Ignazio. 1970. The Story of a Humble Christian. Translated by William Weaver. London: The Camelot Press, Ltd.

Spadaro, S. J. Antonio. 2013. A Big Heart Open to God: The Exclusive Interview with Pope Francis. America. September 3. Available online: https://www.americamagazine.org/faith/2013/09/30/big-heart-open-godinterview-pope-francis (accessed on 21 August 2019).

Stille, Alexander. 2000. The Spy Who Failed: Did the Great Anti-Fascist Novelist Ignazio Silone Betray His Cause? The New Yorker, May 15, 44-48.

Sweeney, Jon M. 2012. The Pope Who Quit: A True Medieval Tale of Mystery, Death, and Salvation. New York: Image Books.

Wooden, Cindy. 2018. Pope Francis: 'Elitist, Clericalist' Church Allows Abuse to Thrive. America. September 13. Available online: https://www.americamagazine.org/faith/2018/09/13/pope-francis-elitist-clericalist-churchallows-abuse-thrive (accessed on 21 August 2019).

(C) 2019 by the author. Licensee MDPI, Basel, Switzerland. This article is an open access article distributed under the terms and conditions of the Creative Commons Attribution (CC BY) license (http://creativecommons.org/licenses/by/4.0/). 